\title{
IL2 Receptor Antibody
}

National Cancer Institute

\section{Source}

National Cancer Institute. IL2 Receptor Antibody. NCI Thesaurus. Code C124045.

Any antibody that recognizes an interleukin 2 receptor protein. 